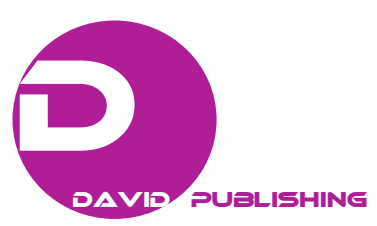

\title{
Impacts of Stockbreeding on Global Warming
}

\author{
Murat DURMUŞ and Nazan KOLUMAN \\ Departement of Animal Science, Çukurova Üniversity, Faculty of Agriculture, Adana 01330, Turkey
}

\begin{abstract}
The climate change is globally faced by the entire world and humanity with considerably negative impacts on people who live in undeveloped countries in terms of improvement and fighting poverty and who make production by using natural resources. The United Nations Development Fund prepared a Human Development Report on "Fighting Climate Change," indicating that there are almost 2.6 million poor people in the world will bear the brunt of climate change and ecological conditions. In this respect, emphasis must also be put on the need for considering the people whose source of income usually originates from animal production. In this sense, climate change poses an obstacle on success of the work which is conducted to achieve millennium development goals. The observable changes emerging in climate particularly increases in atmosphere temperature in some regions have an impact on biological life in many regions of the world. Animal production has been considerably intensified in order to meet animal protein deficit which is suffered by the increasing population. The impacts of conventional applications aimed at increasing productivity in animal production have been negative and the people's attention has started to focus on animal production with the global warming concept and Kyoto Protocol. The animal production might create negative effects on many aspects of environment such as air and water pollution, decrease in soil quality and biodiversity, as well as climate change. The aim of this paper to evaluate animal farming impacts on global warming.
\end{abstract}

Key words: Stockbreeding, climate, global warming, greenhouse gases.

\section{Introduction}

The global warming and climate change are mainly caused by 3 gases, namely, carbon dioxide $\left(\mathrm{CO}_{2}\right)$, methane $\left(\mathrm{CH}_{4}\right)$ and dinitrous oxide $\left(\mathrm{N}_{2} \mathrm{O}\right)$. Moreover, the increased water vapor level in the atmosphere is another factor contributing to global warming. In addition to these gases, it's known that gases with chlorofluorocarbon which have been commonly used in the industry in the past also make considerable contribution. These gases which are naturally produced have no harmful effect. On the contrary, their presence in the atmosphere in normal limits contribute to holding some heat moving away from the earth and establishing the atmospheric conditions ensuring the continuation of life in the earth. However, the high-level release of these gases cause an increase in rational shares on this layer and thus keeps the long- and short-wave infrared rays from the sun on a higher level. It's reported that considering the effects

Corresponding author: Murat Durmuş, Ph.D., main research field: animal science and small ruminant breeding of global warming and assuming the $\mathrm{CO}_{2}$ effect as 1,1 ton of methane corresponds to the effect of 23 tons of $\mathrm{CO}_{2}$, whereas 1 ton of $\mathrm{N}_{2} \mathrm{O}$ equals the effect of 296 tons of $\mathrm{CO}_{2}$ [1]. The intensive emergence of mentioned gases, particularly methane, as a result of agricultural activities, caused people's attention to focus on this issue in the course of Kyoto Protocol.

\section{Carbon Dioxide Emission}

The $\mathrm{CO}_{2}$ is a greenhouse gas which is available in the atmosphere on the highest level and to which importance should be attached. The increasing $\mathrm{CO}_{2}$ level in the atmosphere which has been evident in the last 250 years was caused by rapid decreases in forest lands and intensive use of fossil fuels. The $\mathrm{CO}_{2}$ emission mainly results from the tendency of rapid industrialization which has started in 1970s. The $\mathrm{CO}_{2}$ is a greenhouse gas which is available in the atmosphere on the highest level and to which importance should be attached. The IPCC (2007) reported that the $\mathrm{CO}_{2}$ concentration which was 280 ppm in 1750 had reached 379 ppm in 2005 with an 
increase by approximately $30 \%$ [2]. It's known that the current $\mathrm{CO}_{2}$ emission mainly stems from animal production and equals $9 \%$ of total emission [3]. At this point, emission doesn't directly result from the animal itself. The $\mathrm{CO}_{2}$ which is produced due to the energy used in feed production, manure production, product processing and transportation could be considered a factor. For example, $1 \mathrm{~kg}$ concentration feed production is likely to cause $0.57-2.21 \mathrm{~kg} \mathrm{CO}_{2}$ production, and less $\mathrm{CO}_{2}$ is produced in the production of many rough feed [4]. Similarly, plenty of fossil fuel is utilized in order to acquire artificial manure which is used to produce animal feed and thus 41 million tons of $\mathrm{CO}_{2}$ is produced annually [1]. The nitrogen incorporated into the soil in order to produce animal feed increases the dioxide nitrogen emission. On the other hand, the grasslands which are perished as a result of excessive grazing and the removal of forests in order to open agricultural fields to produce pasture areas and feeds have an impact on the increasing $\mathrm{CO}_{2}$ emission.

\section{Dioxide Nitrogen $\left(\mathrm{N}_{2} \mathrm{O}\right)$ Emission}

The herbal products which are used as food for animals aren't sufficient alone for a balanced nutrition. In addition to herbal production, the food obtained from animals as a result of using these resources is also of utmost importance in terms of nutrition. Approximately $50 \%$ of the corn produced in the world and $80 \%$ of soybeans are used in animal production. The corn production involves considerable use of nitrogenous manures [5]. Therefore, the amount of nitrogen incorporated into soil in order to produce feed reaches serious levels. The addition of large-sized synthetic manure (nitrogen) into the soil has deteriorated the global nitrogen cycle to a great extent. The manures consisting of excessive nitrogen addition which are used for herbal production increase the level of substances with nitrogen in water resources. Another serious issue which should be emphasized is millions of tons of animal manures. The nitrogen pollution dramatically affects the water and air, and thus the life quality of societies living near animal production areas is negatively influenced by this situation. The manure lagoons at large-scaled animal production farms are likely to leak and mix into floods and rivers. The most important examples to this situation is the fire, dead fish and extensive environmental pollution which were caused by the discharge of a manure lagoon from a pig raising enterprise in the US to New River in 1995 and the discharge of a manure lagoon at a milk cow enterprise into the Black River in 2005 [6].

The nitrogen is also likely to create serious impacts on global warming. For example, dioxide nitrogen $\left(\mathrm{N}_{2} \mathrm{O}\right)$ is very important in this respect. The GWP (Global Warming Potential) of this gas is important due to two reasons. Firstly, it leads to shrinking in ozone layer; secondly, its concentration in the atmosphere has increased in the last 150 years in an unprecedented way. In a study on dioxide nitrogen amount reported that the current concentration is higher than the one in 1780 by $16 \%$ [1]. Once the manures of ruminants such as cattle, sheep, goat, buffalo and camel are stored, largeamounts of dioxide nitrogen gas are released as well. Approximately $70 \%$ of global $\mathrm{N}_{2} \mathrm{O}$ emission derives from plant and animal production, $65 \%$ of which results from animal production [1]. Similarly, once the pig and poultry manures are stored in liquid forms under unventilated conditions, they become importantmethane and $\mathrm{N}_{2} \mathrm{O}$ emission resources. In order to decrease the dioxide nitrogen emission [3, 4, 7], following suggestions are made:

- The amount of nitrogen which is applied along with manures should be decreased;

- Animals' productivity should be increased, whereas the number of animals should be decreased (but this situation poses an economic problem to farmers);

- The amount of nitrogen applied on soil for crop production should be decreased; 
- The amount of nitrogen used in animal feeding should be decreased (but this nutrition might increase the methane emission due to imbalanced nutrients).

\section{Methane Emission}

The global warming potential of methane is 23 times higher than that of $\mathrm{CO}_{2}$ and its concentration in the atmosphere has increased by $150 \%$, when compared to 1750 . The animal production is held responsible for $16 \%$ of methane production which is caused by human activities [1]. In a study on methane emission calculated that $39 \%$ of the annual methane emission originating from agriculture is caused by enteric fermentation, 29\% from rice production areas, $19 \%$ from burning of crop wastes and 12\% from animal wastes [8]. In another study, on methane emission calculated the contribution made by non-biological factors as $32 \%$, rice production areas as $18 \%$, ruminants as $18 \%$, marshes as $13 \%$ and other factors as $6 \%$ [9]. The amount of methane which is individually produced by animals is quite low. For example, a mature cow produces approximately $80-110 \mathrm{~kg}$ methane annually [4, 10]. The main problem related to ruminant is that their presence in the world has reached nearly 1 billion [11] and that this number makes serious contributions to emission. The enteric methane production is likely to reach approximately $15-18 \%$ of digestible energy taken from the cattle which are fed with bad-quality rough feed. This situation results from the lack of food substances and balance in the ration for rumen microorganisms and thus the insufficient and inefficient microbial development. The amount of methane released from the beef and milk cattle to atmosphere in the US constitutes $71 \%$ of methane and $19 \%$ of total methane emission [1]. The contribution made by animal production to methane production is caused by low enteric fermentation efficiency and high methane production capacity of the manure. The high methane-producing capacity of stored manures cause poultry and pig manures to become serious methane resources. The methane emission caused by the pig manure constitutes approximately half of the methane emission deriving from the livestock manure in the world. In case the global warming and climate change continue their courses in estimated speed, they might lead to drought, famine and social conflicts, because the desertification and change of settlements in the world, decrease in food production and inability to meet water needs will become the basic reason of social conflicts. In such cases, the sections of community who will be mostly influenced by this situation are farmers and agricultural sector. The number of people dealing with animal production in the world is approximately 2 billion. The stockbreeding is their only source of income and there are some people who lead a life by grazing nearly 200 million animals.

\section{Ways of Decreasing the Greenhouse Gas Production originating from Animals}

As generally discussed before, the direct animal contribution in the greenhouse gas emission originating from animals is caused by enteric fermentation. The others are caused by indirect ways such as feed production, product processing and transportation, manure storage and its use in crop production. The most important greenhouse gas which is released during these processes is methane. The methane emission directly originating from animals is caused by inefficient fermentation, namely the food substance of feed in rumens, and inability to meet the food substance needs of microbial flora in a sufficient and balanced way. The activation of microbial fermentation activity both in digestive system and manure lagoons plays an important role in terms of decreasing the greenhouse gas emission to be produced. As indicated before, the basic principle with regard to decreases in greenhouse gas production directly originating from animals will be performed by increasing the efficiency of food nutrients in the digestive system. The methane production derives 
from fermentation under unventilated conditions. After food substances are decomposed in the rumen, they are fermented to volatile oil acids, hydrogen, $\mathrm{CO}_{2}$ and $\mathrm{NH}_{3}$, incorporated into $\mathrm{CO}_{2}$ hydrogen and finally reduced to methane $\left(\mathrm{CO}_{2}+4 \mathrm{H}_{2}-->\mathrm{CH}_{4}+2 \mathrm{H}_{2} \mathrm{O}\right)$ under unventilated conditions. Furthermore, the hydrogen which is produced under unventilated conditions could be used to produce volatile oils (Hydrogen production: $\quad$ Pyruvate $\rightarrow$ Acetate $(\mathrm{C} 2)+\mathrm{CO}_{2}+2 \mathrm{H}$; Hydrogen usage: Pyruvate $+4 \mathrm{H} \rightarrow$ propionate $(\mathrm{C} 3)+\mathrm{H}_{2} \mathrm{O}$ or $2 \mathrm{C}_{2}+4 \mathrm{H} \rightarrow$ butyrate $(\mathrm{C} 4)+2 \mathrm{H}_{2} \mathrm{O}$ ). At this point, the aim is to direct the fermentation from acetate towards propionate. In this case, the methane production decreases and the energy usage efficiency is improved. The previous studies primarily deal with increasing the digestibility of food substances in ration. In a study reported that a rise in the rate of rough feed in ration increased the methane production, different starch resources are effective in methane production and the corn is likely to increase methane production in rations based on rough feed, whereas barley could do the same in rations based on concentrate feed [12]. Similarly, in case oil is used in the ration as a source of energy, the microbial flora and energy usage efficiency change in the rumen and thus the methane production decreases [12]. This situation emerges as a result of a decrease in fermentability of the feed by using oil and the inhibition of protozoa. Furthermore, different species of a particular cereal could produce different levels of methane. In a study on lambs reported that 4 different varieties of barley produced methane in different ways [13]. Similar indications were reported with regard to rough feed (ryegrass varieties) [14]. In line with these assessments, given such manipulations as the energy resource which is used in ration (rough/concrete feed rate, cereal resource, using oil instead of starch), it's considered necessary to put forth ways of limiting the methane production to more comprehensive studies.

In a research about impacts of the concentrate feed rate on the methane production in ration of carnivorous heifers, to compare the clover fodder by $75 \%$ to the concentrate feed content by $75 \%$ and finally determined that the energy loss caused by methane greatly decreased in high concentrate feed areas [15]. Similarly, in another study put forth that the methane emission falls away in the beef cattle consisting of the concentrate feed addition into the ration [16]. In another study observed that the methane production decreases with an increase in cereal rate in the ration of sheep [17]. They considered that this decrease derived from the rumen $\mathrm{pH}$ which falls with an increase in the concentrate feed, a fall in methanogenes which are sensitive to low $\mathrm{pH}$, a decline in the number of protozoa and the duration of concentrate feed presence in ration of the digestive system (the duration of fermentation gets shorter), an increase in propionate production which is among the most important incidents in the course of moving away the hydrogen which is formed in rumen and thus a decrease in the acetate/propionate rate. The oil, which is among the energy resources used in ration, is also capable of decreasing methane production to a great extent. In the study used raw flaxseed, extrude flaxseed or flaxseed oil in milk cattle rations as part of a study and concluded that the amount of methane has greatly declined in the cattle which consume the rations from which oil is obtained by $5.7 \%$ [18]. In another study used monensin, sunflower oil, enzymes, ferment and fumaric acid to decrease the methane emission in the beef cattle and determined that the use of oil in the ration decreases the methane production to a great extent [12]. Besides, in a study conducted on the Black Spotted cattle and reported that in case soybean oil is used by $3.5 \%$ in rations which are arranged in the form of Total Mixed Ration (TMR), the methane and $\mathrm{CO} 2$ production remained unchanged [19]. The reasons of decreases which were observed in the use of oil in rations and methane production are indicated as follows:

(1) Some hydrogen in the rumen is used to feed unsaturated oil acids and thus the amount of hydrogen 
is decreased for methane production;

(2) Both the cellulose fermentation and the acetate/propionate rate decrease due to negative impacts of oil acids on microorganisms;

(3) The number of protozoa where the metanogene bacteria live symbiotically decreased.

Furthermore, it reported that the methane production limitation is among the issues which have been researched the most recently and that probiotics, organic acids and plant extracts could be used towards these ends [20]. As indicated before, the aim is to manipulate the rumen fermentation and move it to the desired way in such applications. But it can be said that usually in vitro and in vivo results of studies which are conducted on this issue aren't compatible and that it's impossible to obtain compatible results in similar studies either. It reported that important results had been obtained from certain studies which were conducted in order to decrease the methane emission in ruminants with the use of natural herbal feed additives [21]. Researchers stated that plant secondary components were likely to decrease the methane production and plants consisting of saponin, tannin and volatile oils among the plants containing secondary components played important role [22]. Researchers stated that plants consisting of both saponin and tannin decrease the number of protozoa in rumens and thus the methane production. In a study determined that the fennel, clove, garlic, onion and ginger volatile oil inhibited in vitro methane production [23]. In another study reported that total methane emission of the essential oil which is used in ration, methane production per dry matter intake in $\mathrm{kg}$ and the energy which is lost due to methane as the percentage of gross energy intake remained unchanged [24].

The amount and efficiency of secondary plant components differ, depending on the region they are picked and their location. The efficiency of plant extracts depend on their antimicrobial content, anti-protozoal and antioxidant substances. The botanic composition of our country provides great advantages with regard to producing plant essential oils and diversity. Therefore it's of utmost importance to determine the enteric methane production decreasing capacities of plant volatile oils available in our country. The antimicrobial, antiprotozoal and antioxidant qualities of plant volatile oils were commonly researched, but their potentials impacts on methane emission remains unknown. The productivity in ruminants directly depends on improving the efficiency of food substances utilization in the rumen. The optional feeding studies which were recently conducted, reported that the optional feeding is likely to improve the efficiency of food substances utilization in the rumen and provide the manipulation and optimization of rumen fermentation [25-27]. The animals which are fed optionally allow the optimization of rumen conditions and synchronization of rumen microorganisms, as well as animals' food substance needs, because animals are free to take feed whenever they need and in required quantities. Methane and $\mathrm{CO}_{2}$ emission decreased in the sheep which are fed optionally. In this respect, it's considered that the impacts of optional feeding, which are carried out under different physiological conditions and in diverse species, on the greenhouse gases production should be put forth [28, 29].

\section{Conclusion}

As a conclusion following recommendation could be taken into account:

- Animals' productivity should be improved and the number of animals should be decreased;

- The rate of rough feed should be decreased and the concentrate feed rates should be increased in order to improve the digestibility of feed;

- The rough feed and grassland feed crops should be produced to ensure less greenhouse gas release;

- Alternative feed crops and concentrate feed with rich content of such substances as tannin and sanopin should be used; 
- The vegetable oil should be added into the ration;

- The secondary plant components such as volatile oils should be used to feed animals;

- The use of probiotics which are likely to suppress and compete with methanogene microorganisms should be discussed as appropriate methods;

- The rough feed of high quality should be used, the amount and quality of pasture areas and grasslands should be improved, the plant pattern and appropriate cultivation pattern which are resistant to heat and diseases should be projected;

- Once the technological applications aimed at improving the quality of agricultural waste, the digestibility levels of such substances in the course of using them to feed animals will be able to be improved.

\section{References}

[1] Steinfeld, H., Gerber, P., Wassenaar, T., Castel, V., Rosales, M., and De Haan, et al. 2006. Livestock's Long Shadow: Environmental Issues and Options. Rome, Italy: Electronic Publishing.

[2] IPCC, 2007. Climate Change: Synthesis report. Fourth Assessment report.

[3] Clark, H., de klein, N., and Newton, P. 2001. Potential Management Practices and Technologies to Reduce Nitrous Oxide, Methane and Carbon Dioxide Emissions from New Zealand Agriculture: A report Prepared for Ministry of Agriculture \& Forestry.

[4] O'Mara, F., 2004. "Greenhouse Gas Production from Dairying: Reducing Methane Production." Advances in Dairy Technology 16: 295-309.

[5] HSUS, 2006. HSUS Fact Sheet: Animal Agriculture and Climate Change. Food and Agriculture Organization report.

[6] NYSDEC, 2006. New York State Department of Environmental Conservation. New York State's Environmental Production and Regulatory Agency.

[7] Gworgwor, Z. A., Mbahi, T. F., and Yakubu, B. 2006. "Environmental Implications of Methane Production byRuminants: A Review." Journal of Sustainable Development in Agriculture and Environment 2 (1): 1-14.

[8] Houghton J. T., Callander, B. A., and Varney S. K. Ed. 1992. Climate Change. Cambridge, Cambridge University Press.

[9] Bolin B., Doos, B. O. R., Jager, J., and Warrick R. A. Eds. 1986. Trace Gases in the Atmospheres. The Green House Effect, Climate change and Ecosystems (SCOPE 29)
Chichester: Wiley and Sons.

[10] U.S.E.P.E., 2008. Environmental Protection Agency. Ruminant Livestock: Frequent Questions.

[11] FAO, 2008. Food and Agriculture Organization of the United Nations. FAO Statistical Database, FAOSTAT.

[12] McGinn, S. M., Beauchemin, K. A., Coates, T., and Colombatto, D. 2004. "Methane Emissions from Beef Cattle: Effects of Monensin, Sunflower Oil, Enzymes, Yeast and Fumaric Acid." Journal Animal Science 82 (11): 3346-3356.

[13] Ovenel-Roy, K. H., Nelson, M. L., Westberg, H. H., and Froseth, J. A. 1998. "Effects of Barley Cultivar on Energy and Nitrogen Metabolism of Lambs." Canadian Journal of Animal Science 78 (3):389-397.

[14] Lovett, D., Lovell, S., Stack, J., Callan, J., Finlay, M., Conolly, J., et al. 2003. "Effect of Forage/Concentrate Ratio and Dietary Coconut Oil Oil Level on Methane Output and Performance of Finishing Beef Heifers." Livest. Prod. Sci. 84 (2):135-146.

[15] Reynolds, C. K., Tyrrell H. F. and Reynolds, P. J. 2001. "Effects of Diet Forage-to-concentrate Ration and Intake on Energy Metabolism in Growing Beef Heifers: Whole Body Energy and Nitrogen Balance and Visceral Heat Production.” J. Nutr. 121 (7): 994-1003.

[16] Oliveira, S. G., Berchielli, T. T., Pedreira, M. S., Primavesi, O., Frighetto, R. and Lima, M. A. 2007. "Effect of Tannin Levels in Sorghum Silage and Concentrate Supplementation on Apparent Digestibility and Methane Emission in Beef Cattle." Anim. Feed Sci. Technol. 135 (3): 236-248.

[17] Cristophersen, C. T., Wright, A. D. G., and Vercoe, P. E. 2008. "In Vitro Methane Emission and Acetate: Propionate Ratio are Decreased When Artificial Stimulation of the Rumen Wall is Combined with Icreasing Grain Diets in Sheep." Journal of Animal Science 86 (2): 384-389.

[18] Martin, C., Rouel, J., Jouany, J. P., Doreau, M., and Chilliard, Y. 2008. "Methane Output and Diet Digestibility in Response to Feeding Dairy Cows Crude Linseed, Extruded Linseed, or Linseed Oil." Journal of Animal Science 86 (10): 2642-2650.

[19] Sauer, F. D., Fellner, V., Kinsman, R., Kramer, J. K., Jackson, H. A., Lee, A. J., et al. 1998. "Methane Output and Lactation Response in Holstein Cattle with Monensin or Unsaturated Fat Added to the Diet." Journal of Animal Science 76 (3): 906-914.

[20] Newbold, C. J., and Rode, L. M. 2006. "Dietary Additives to Control Methanogenesis in the Rumen." International Congress Series 1293: 138-147.

[21] Wallace, R. J. 2004. "Antimicrobial Properties of Plant Secondary Metabolites." Proceedings of the Nutrition Society 63 (4): 621-629. 
[22] Kamra, D. N., Agarwal, N., and Chaudhary, L. C. 2006. "Inhibition of Ruminal Methanogenesis by Tropical Plants Containing Secondary Compounds.” International Congress Series 1293:156-163.

[23] Patra, A. K., Kamra, D. N., and Agarwal, N., 2006. "Effect of Plant Extract on in Vitro Methanogenesis, Enzyme Activities and Fermentation of Feed in Rumen Liquor of Buffalo." Anim. Feed Sci. Technol. 128 (3): 276-291.

[24] Beacuchemin, K. A., and McGinn, S. M., 2006. "Methane Emissions from Beef Cattle: Effects of Fumaric Acid, Essential Oil and Canola Oil." Journal of Animal Science 84 (6): 1489-1496.

[25] Görgülü, M., Kutlu, H. R., Demir, E., Öztürkcan, O., and Forbes, J. M. 1996. "Nutritional Consequances of Free-Choice Among Feed İngredients By Awassi Lambs." Small Ruminant Research 20: 23-29.

[26] Görgülü, M., Güney, O., Torun, O., Özuyanik, O., and
Kutlu, H. R., 2003. “An Alternative Feeding System for Dairy Goats: Effects of Free-Choice Feeding on Milk Yield and Milk Composition of Lactating Suckling Damascus Goats." Journal of Animal and Feed Sciences 12: 33-44.

[27] Görgülü, M., Boğa, M, Şahin, A., Serbester, U., Kutlu, H. R., Şahinler, S. 2008. "Diet Selection and Eating Behaviour of Lactating Goats Subjected to Time Restricted Feeding in Choice and Single Feeding System." Small Ruminant Research 78:41-47.

[28] Yurtseven, S., and Ozturk, İ. 2008. "Influence of Two Sources of Cereals (Corn or Barley), in Free Choice Feeding on Diet Selection, Milk Production Indices and Gaseous Products (CH4 and CO2) in Lactating Sheep." Asian Journal of Animal and Veterinary Advances 4 (2): 76-85.

[29] Özcan, N., Özcan, B. D., Göncü Karakök, S. 2008. Küresel Isınma Koşullarında Tarımsal Üretimin Geleceği. Mersin Sempozyumu, İçel/Türkiye. 